\title{
Improvement of Measures to Counteract Raider Acquisition of Kuzbass Coal Mining Enterprises
}

\author{
Tatyana Tuleneva ${ }^{1, *}$ \\ ${ }^{1}$ T.F. Gorbachev Kuzbass State Technical University, 650000 Vesennya st. 28, Kemerovo, Russian \\ Federation
}

\begin{abstract}
The paper deals with ways of fight against raider acquisitions of enterprises at different levels of management. Creation of institution of raiding is due to imperfections of market-based instruments for redistribution of ownership, a lack of regular market valuation of liquid assets of enterprises, unclear system of registration of property rights, low information clarity of the data, growth of corporate conflicts, imperfection of corporate legislation. The effect of raider acquisitions is damage to economy, social sphere and investment climate of Kuzbass and Russia. The wave of raiding is now aimed at coal mining enterprises of Kuzbass, which have a stable holding structure and rising property prices due to the development of strategic markets. Effective fight against raiding is possible only with using of a systematic approach. This means development of activities of legal protection from raiders and elimination of inequalities company's laws to the current legislation. At the state level it involves publication of relevant legal acts to combat raiding. For effective fight against raiding at the level of the enterprise it is necessary to develop in advance a complex of preventive measures of protection taking into account characteristic features of its activity.
\end{abstract}

\section{Introduction}

Economic crisis leads to aggravation of conflict of relations in the sphere of business, formation of new methods and accompanying ways of capture of enterprises, attraction of new subjects participating in a chain of raiders' actions, and also to need of change of the criminal and criminally-procedural legislation in fight against this illegal phenomenon. Officially recognized that raiding is a state-size problem, solution of which requires monitoring at the highest level, and main way of combating this criminal phenomenon is the fight against it by using criminal law measures.

Despite the fact that the era of «dashing 90 -ies» is a thing of the past, such actions as raider acquisition on enterprises, unfortunately, still accompany Russian reality. Organized crime has become more inventive than ever. Raiders often operate within the law, using accounting documents, information about activity of a company and rely on professional lawyers. So the question about protection business from raiding becomes more important,

\footnotetext{
* Corresponding author: kta.bua@kuzstu.ru
} 
as raiders try to act within the law. In many cases, it is not necessary to count on the assistance of law enforcement agencies.

The wave of raiding began to move to regions, because in Russia's center property is already divided and securely protected. Coal-mining enterprises of Kuzbass aren't left without raiders' attention. The year 2017 is characterized by increased treat of raider acquisitions, we can realize this fact from following publications in the media [1].

1. The attempt to raider's acquisition of mine «Anzherskaya-Yuzhnaya» with using of force measures. Armed men in masks announced change of leadership, didn't allow on a territory of the mine more than 300 miners, expelled employees from offices of the enterprise, and also tried to turn coalface off power supply, where there were miners. Employees of Main investigation department of the Main investigation department of GD IAM of Russia in Kemerovo region managed to come to organizer's trail of action, "which immediately went by plane to Moscow after committing illegal actions, where he was detained by local police in an airport « (as it was said in a press release GD IAM). Prerequisites of these actions was the bankruptcy procedure of LLC «JED Block № 2 of mine «Anzherskaya-Yuzhnaya», and one of the first decisions of the new bankruptcy trustee was a ban on shipment of coal in the continuation of its production (that means the actual stopping of coal mining after filling the coal warehouse), and also his decision to transfer functions of security to another company, which was represented by people in masks.

2. The conflict between new owner of CC «Zarechnaya» (LLP «Coal of Kazakhstan») and Kemerovo region Administration concerning payment of debts to Gazprombank. The regional administration accused the owner of failure to pay the debt formed before bankruptcy proceedings, despite anti-crisis measures to improve the solvency and efficiency of production, which gave a positive result. Gazprombank refused to enter into a settlement agreement with the new owner, despite his aspiration to repay the debt, and sold the debt to a new creditor interested in the bankruptcy of the CC «Zarechnaya».

Raiding often takes place in a hidden form, so it is almost impossible to calculate the damage in monetary terms [2]. It damages the state, destroys economy and legal order. Raiding hinders innovation policy. Many economic processes in Russia involve foreign owners [3].

\section{Object of Research}

Existing legal framework in the country doesn't allow to share civilized methods of business in field of consolidations and acquisitions and illegal seizures of enterprises. There is no systemic corporate law. There is also a clear lack of comprehensive research on protection of business in Russia from the standpoint of economy and politics.

In Russia, this sphere of activity is characterized by a high level of criminalization: almost all cases of hostile acquisitions are accompanied by violation of both civil, administrative, financial and criminal law. Corporate seizures of enterprises in Russia began in the 90 -ies of last century after privatization. Many employees of large state-owned enterprises and organizations have become shareholders of new economic entities. Then there were no shares, but as a result there was an economic crisis and led to a reduction in workers. Therefore a virtual share package was formed, which raiders needed.

Economic damage from raiding is impossible to identify completely, because seizure takes place in a hidden form. There is another factor that has a very negative impact not only on the Russian economy, but also on its social life, is reduction of jobs. In today's Russian economy there is an institutional lack. This is evidenced by widespread phenomenon of raiding in Russia, because it replaces institutional, or legal, order. This phenomenon disturbs activity on normal segment of institutional market economy, such as 
market of consolidations and acquisitions. In general raiding is substitution of the market because it is acquisition, but not market agreement [4].

In Russian conditions raiding leads to a variety of negative consequences, which are acute in short term. At the same time peculiarities of Russian institutional environment block possibility of effective using of solutions that have proven themselves in other countries, and establish the need to develop policies taking attention Russian specifics.

Consequence of raiding is economic damage to coal mining enterprises, which destroys social sphere, becomes a threat to security of the state, destroy overall investment climate in the region. Raiders' acquisitions often lead to collapse, because they need spend considerable money on legal «cleaning» of its assets find a person is able to manage production after paying for their services to the new owner. Usually this fact leads to serious losses. And since the process of seizure in $99 \%$ of cases includes criminal acts from racketeering and force influence to banal forgery of documents, the customer needs to be ready that newly acquired property can be taken away [5]. And this fact badly affects development of any business.

Almost never manage to bring raiders to justice due to the lack of relevant articles of the Criminal code or relevant Federal law. Also degree of bureaucratization of almost all departments prevents protection from raiding. Statements from victims are routed from one department to another, courts consider applications for months, and at the same time successful businesses are moving into the wrong hands and are often subject to looting. Because of peculiarities of life in the country in the past years there are such tool in the arsenal of raiders, as a challenge to results of privatization. Statute of limitations on most privatization transactions has already expired. Therefore, even in large cases, claims and charges related to tax or credit schemes are used.

As a rule, a coal mining enterprise becomes a target to raiders as a result of whole complex of erroneous actions committed by its owners or managers [6]. Each head of the company should be very attentive to issues of information security, especially to the protection of information on accounting and personnel. As a rule, raiders seek to introduce their people to key positions of the coal mining enterprise before moving to its acquisition. Accordingly, the head of coal mining enterprise must keep personnel issues under special control, check candidates for vacancies. Secondly, raiders often have compromising material on the owner of a coal mining company. Lack of compromising materials is a serious problem for raiders [7]. Accordingly, care should be taken to ensure that unnecessary information not only about the enterprise, but also about life of managers and owners didn't become property of strangers.

More specific ways of protection against raiding include strengthening the security system of coal mining enterprise, including hiring of armed guards for both apartments of an enterprise and for its leaders; ensuring the security of business documents, primarily the constituent, financial and personnel; obtaining a small loan from a banking institution secured by enterprise's property, in this case, there will be another way to force raiders to eliminate their plans (but this scheme works only if bank is reliable); distribution of existing contracts to affiliated organizations; repayment of all taxes and lease payments, which will exclude possibility of using debts to acquisition the business.

The solution to the problem of acquisition of enterprises is important not only for the coal industry of Kuzbass, but also for the country as a whole. As a result of conventional concept of ownership in the country, the possibility of external financing is excluded, the export of capital abroad is induced, development of production is stopped, investment in the coal industry is limited [8]. This process leads to decline not only of private business and the economy, but also of the country as a whole.

In contrast to active methods of corporate protection against hostile acquisition applied during the acquisition, preventive methods of protection are more effective. Firstly, it is 
possible to prevent an acquisition. Secondly, the target company may not have enough time to implement methods of protection in the case of an acquisition. Thirdly, the cost of protective measures can significantly increase in conditions of limited time. Main methods of preventive corporate protection in Russia (in contract to foreign) are few. These methods of protection is often called «hedgehogs ' tossing», the essence of which is to discourage the initiative from raiders to the acquisition of the target company. These methods are following [9].

1. Reorganization of target company. This method means changing the organizational and legal form, for example, to transfer PC to JSC or to convert it to LLC. The meaning of this change is to limit the circulation of shares (JSC) or the conversion of shares of JSC into shares of LLC. After transformation into LLC changing of a ratio of shares will be complicated by need of modification its constitutive documents.

2. Restructuring of assets. As it mentioned above, the target company becomes interesting for raiders if it has immovable property and expensive movable one (production equipment), which is its main asset. The essence of this method is to withdraw assets of the target company to subsidiaries and affiliates of the target company.

3. Restructuring of liabilities. In this case it means additional issue of ordinary registered shares or bonds of the target company and distribute them among persons controlled by main owners.

4. Control of accounts payable. The essence of this method of protection is to prevent overdue debts and strict control of treaty provisions with creditors.

5. Looking for a friendly buyer («White knight»). This method assumes that potential target company must obtain support of a large friendly company in advance, which will help the target company to acquire its shares in case of acquisition.

6. Creation of controlled accounts payable. The name of method means that potential target company deliberately generates accounts payable among subsidiaries or friendly companies.

7. Amendments to the Charter of a potential target company. The target company's Charter introduces provisions limiting the possibility of hostile acquisition, such as formalization of the procedure of shareholders' meeting, complication of the procedure of the Board of Directors' election, presentation of special requirements to the General Director's candidate, limitation of powers of the General Director, etc.

8. Reducing the number of minority shareholders of the target company. This method of protection involves buying shares from minority shareholders, which reduces the probability of corporate racketeering and increases percentage of ownership of shares from main owners of potential target company. This measure increases the chance of making all decisions for the target company at the general meeting of shareholders.

Current Criminal code of Russian Federation provides for preventive measures that should prevent unscrupulous collection of information about the company, which may be target of raiders. These are articles 137 (violation of privacy), 138 (violation of confidentiality of correspondence, telephone conversations, postal, telegraphic or other messages), 183 (illegal receipt and disclosure of commercial, tax or banking secret information), 272 (illegal access to computer information). However none of these structures of crimes doesn't lead directly to acquisition of the enterprise by adoption of illegal administrative decision or stealing of shares. More aggressive raiders are at following stages of acquisition of the enterprise. These may include articles 119 (threat of death or serious bodily harm), 159 (fraud, usually committed by a group of persons by prior agreement and often accompanied by stealing of shares), 163 (racketeering, or forcing the shareholder to sell shares), 179 (forcing to make a transaction or to refuse to make it), 303 (falsification of evidence in order to obtain knowingly wrongful judicial acts that could be 
used in the raider acquisition). For hindering to be on a shareholders' meeting it can be arranged kidnapping (article 126) or illegal deprivation of liberty (article 127).

\section{Results and Discussion}

Some of possible preventative methods to fight against acquisitions of coal mines can be careful selection of experts in management bodies of the company, organization of effective work of lawyers and the security services, involvement for protection of the company or office of the private security, compliance by the company with trade secrets, monitoring of all attempts to obtain information about the company and its immovable property from USRLE, from the State register of rights to immovable property and State land cadastre by strangers, insurance of title rights to shares by major shareholders, permanent internal audit, inspection of internal condition of documents, verification of seals, protection against forgery, making such provisions in the company's Charter that may make it difficult to acquire the company, introduction of mechanisms that can protect owners from loss of shares / stocks and from their stealing [10].

Thus, for to effectively counter raiding it is necessary to develop a set of preventive measures in advance, taking into account characteristics of the coal mining enterprise. This measure will significantly reduce the risk of illegal acquisition. It is necessary to build a clear management system, which includes regular monitoring status of documents, regular changes in constituent documents, implementation permanent internal audit with the assistance of lawyers in order to thoroughly study and eliminate gaps and contradictions with the legislation in the documentation [11].

Effective control at the state level should include legislative activity, determining the concept of raiding, in which it is necessary to clearly define the concept and possible scope of acts covered by this phenomenon, introduction of criminal responsibility to participants of the raider acquisition, publication of normative legal acts on fight against raiding, including allowing to prevent possibility of submission to the registration authority of inaccurate information; development of measures to ensure thorough verification of documents submitted for registration with the Federal registration service and the Federal tax service; study of international experience in fight against raiding.

A lot depends on the Federal laws. Unfortunately, raiders often exploit the ambiguity of such laws for unseemly purposes [12]. Clearly there is a certain lag of commercial, administrative and criminal legislation from life. If legislation and regulations are not amended in a timely manner, there will still be places in laws by which other people's property will be acquired. Such situation could destroy Russia's image as a rule-of-law state with a market economy. And this fact will force many western businessmen to refrain from investing their funds in Russian economy.

Activity to improve ethics of business relations should be a priority for the business community in fight against corruption and other threats to security of coal mining enterprises. Public associations and movements of businessmen don't show proper practical activity in order to increase a culture of business relations, rejection of persons and entities that violate law and business ethics, doing business on a criminal basis or covering business openly criminal activities by business community. Combined efforts of business community to give business the qualities of integrity and social responsibility are clearly insufficient. Overcoming threats to business, giving it properties of integrity and social responsibility and elimination of destructive administrative decisions requires setting this ctivity on a scientific basis [13]. Positive experience in business security, proposals and recommendations for its protection need to generalize and disseminate.

One of planned active actions in the field of elimination corruption in Russian economy is using principle of «one window» in all institutions. This is a cardinal and very timely 
way of fight against corruption, when direct communication with the official is virtually excluded, when passage of the document doesn't depend on personal sympathies or antipathies of a particular official, who is simply turned off from the decision-making process, turning into an executor of law and job descriptions [14].

It should also paid attention to the enterprise management system. This measure includes protection of shareholders' rights, equal treatment to shareholders, timely and accurate disclosure of information on all material facts relating to the corporation and its availability to shareholders, effective control by the management Board and its accountability to shareholders [15].

\section{Conclusion}

In the current context of criminalization of economic relations, raiding has become rather widespread and poses a real threat to the economic security of Russian Federation. This is an extremely dangerous criminal activity for the society and the state, which prevents increasing the efficiency of the national economy, compromises the economic policy of the state, reduces public confidence in the state authorities and destroys the authority of Russia in the international arena. Therefore, at present, the development of measures to counter raiding in order to eliminate causes of this phenomenon, and the implementation of such measures in the context of ensuring the economic security of Russian Federation is of paramount importance.

Effective counteraction to raiding is possible only under condition of system approach at which activity in three directions at the same time will be conducted. Firstly, the tactics of legal resistance to raiders must be worked out. Secondly, a real fight against corruption is necessary. Finally, the basic principle of this process will be elimination of all inconsistencies of company's internal documents with current legislation.

\section{References}

1. A. Ledeneva, Comparative Studies in Society and History, 50(1), 118 (2008a)

2. N. Anderson, The Journal of Labor and Society, 9(2), 225 (2006)

3. A. Osipian, Innovation: The European Journal of Social Science Research, 23(2), 101 (2010)

4. C. Alger, NYU Journal of Law and Business, 3, 309 (2006)

5. J. Pearce, R. Robinson, Business Horizons, 47(5), 15 (2004)

6. E. Demidova, Problems of Economic Transition, 50(5), 44 (2007)

7. T. Firestone, The International Lawyer, 42(4), 1207 (2008)

8. A. Kireev, Problems of Economic Transition, 50(8), 29 (2007)

9. J. Armour, D. A. Skeel, Georgetown Law Journal, 95, 1727 (2007)

10. I. Kasparova, Problems of Economic Transition, 50(5), 61 (2007)

11. B. Black, R. Kraakman, A. Tarassova, Stanford Law Review, 52, 1731 (2000)

12. E. Burger, The International Lawyer, 38(1), 15 (2004)

13. K. Darden, Politics and Society, 36(10), 35 (2008)

14. I. Iwasaki, Problems of Economic Transition, 50(5), 73 (2007)

15. T. Dolgopyatova, Problems of Economic Transition, 50(5), 7 (2007) 